\title{
CHRISTIAN BIBLICAL ETHICS: THE APPLICATION OF BIBLICAL NORMS TO TODAY
}

\author{
Patrick J. Hartin \\ Department of New Testament \\ University of South Africa \\ PRETORIA
}

\begin{abstract}
Christian theologians give many different interpretations to the Scriptures, particularly with regard to their ethical perspectives and their application to the present. An examination and criticism of various approaches adopted at present to the ethical dimension of the Scriptures is undertaken. A distinction is made between the revealed and lasting message of the Scriptures and the message that is conditioned by culture and hence subject to change. Using the thought of Ricoeur and Hauerwas an approach is presented which attempts to do justice to the twofold polarity of the world of the Bible and the world of today. In order to preserve a scenario of concreteness, attention is given to one practical example, namely the issue of homosexuality. After investigating the Scriptural approach to this question, an attempt is made to see how this issue can be viewed from a Christian perspective in the context of the present world.
\end{abstract}

\section{INTRODUCTION}

When Christians look to the Bible for solutions to their ethical dilemmas and problems, they are faced with the problem of bridging the gap between the world of the Bible and the world of today. What principles influence one's attempt to bridge this gap so that the Bible, which Christians hold as normative and authoritative, may speak to the world of today? This issue becomes far more urgent when one is faced with modern medical questions on which the Bible has very little to say. The scope of this article is methodological. It looks at different approaches that are currently presented as directions for making an ethical decision. As a result of a critique of these approaches an attempt will be made to present principles which are necessary for making an ethical decision. Finally, a practical illustration will be given by referring to the ethical issue of homosexuality - while this topic might not be considered directly speaking a 'medical' issue it is indeed an issue of psychological relevancy. 


\section{A CRITIQUE OF PRESENT APPROACHES TOWARDS INTERPRETING THE ETHICAL RELEVANCE OF THE BIBLE FOR TODAY}

In more recent times the issue of how to view the place of Scripture within ethical decision making has received more and more attention. Curran and McCormick (1984) demonstrate this well in their collection of articles from leading scholars who have been wrestling with this question over the course of the past decade.

One can in fact identify four major approaches towards the use of the Bible in Christian ethical decisions. For a more detailed treatment of these approaches see Hartin (1987 and 1990).

\subsection{An ethics of laws}

Here a one to one relationship is presented between the world of the Bible and the world of today. What is said in the Bible is immediately applied to today's situation. Longenecker (1984:2) sums up this approach well:

It argues that God has given prescriptive laws in the form of commandments and ordinances, which can be found in both the Old and New Testaments. If people want to know what they should do, the laws of God stand objectively before them in written form, and they have only to refer to them.

Dodd is an adherent of this interpretation. He draws a distinction between codes and precepts. Codes give detailed attention to every specific situation that could arise, whereas precepts, on the other hand, aim at giving a direction to one's actions (Curran, 1984:181). A major impetus given to such an approach within the New Testament stems from the prescriptive way in which many of the words of the New Testament writers including those of Jesus himself are presented. When examining the statements of Jesus, pride of place is assigned to loving God (Mark 12:29-30 in quoting Deut. 6:45) and loving one's neighbour (Mark 12:31, quoting Lev. 19:18). Other commandments of the Old Testament are upheld with prescriptive force such as the honour due to one's parents (Mark 7:10; Mat. 15:4, in reference to Ex. 20:12 and 21:17) and the indissolubility of marriage (Mark 10:7-8; Mat. 19:5 in quoting Gen. 2:24). The picture of Jesus as the new Lawgiver dominates Matthew's Gospel (Mat. 5 - 7). Even the Fourth Gospel portrays Jesus' teachings as commandments and one must give obedience to his words (John 13:34; 14:15; 14:21; 15:10,12). The Pauline and Petrine letters also continue this perspective by which the Christian religion is viewed as presenting a new 'commandment' (1 Tim. 6:14; 2 Peter 2:21).

However, such an approach fails to do justice to the biblical message and, I would 
argue, in fact distorts it. Firstly, this perspective fails to take cognizance of the wealth of recent studies which argue for an understanding of the Scriptures first and foremost within the historical and cultural situations of their own time. Curran (1984:183) expresses the argument very clearly when he says:

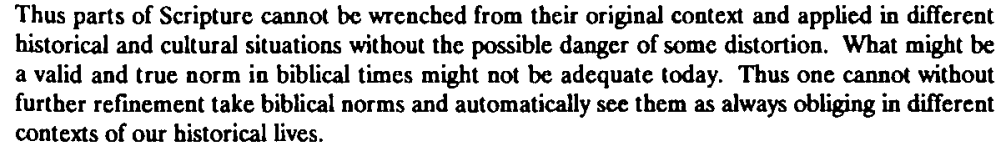

Thus parts of Scripture cannot be wrenched from their original context and applied in different historical and cultural situations without the possible danger of some distortion. What might be a valid and true norm in biblical times might not be adequate today. Thus one cannot without further refinement take biblical norms and automatically see them as always obliging in different contexts of our historical lives.

Secondly, the Bible is meant to be a message of salvation, of the good news of humanity's liberation from the forces of enslavement to the powers of evil. The writers call upon their readers to give a loving and grateful response to this good news. A lawbook approach to these writings presents them as containing demands requiring conformity. Such an attitude does not uphold the free and loving response that should be engendered in the heart of the Christian leading towards action. "Such an approach does not create moral beings, but only controls the worst features of non-moral behavior" (Longenecker, 1984:3). This approach corresponds to the general ethical model known as deontology, which considers ethics from the vantage point of duties, or obligations. When the Bible is viewed simply as a law-book, some further source of interpretation is needed, whether oral or written, in order to apply these laws to different and changing situations, as occurs in the Jewish Rabbinic traditions, and the Roman Catholic ecclesiastical codes of canon law. While these attempts strive to overcome the dichotomy between two different cultural worlds, the danger arises that the traditions become more important than the Scriptures and one has simply replaced one culturally determined perspective (the Scriptures) with another equally culturally determined perspective (the tradition). A clear example of this is found in my own tradition where the Roman Catholic traditional teaching on sexual morality operates with concepts and thoughts of many centuries past. I am not opposed to tradition - in fact as this paper will proceed to indicate that tradition plays a vital role in the interpreting and revitalizing of the Scriptures - but when it fossilizes the Scriptures and acts as a further fossilized layer over that of the Scriptures, the living word of the Scriptures is destroyed.

\section{$2.2 \quad$ An ethics of ideals}

In this framework a decision is made on the basis of ideals that are presented by the Bible. This approach differs from the previous direction in that the individual laws contained within the Bible are not presented as having binding force for the believer. Instead, behind these laws are ideals which present the direction in which the person 
must lead her/his life. This particular approach also corresponds to that traditional approach described in theological ethical manuals as a teleological approach to ethics whereby the ethical nature of an action is judged according to the end or the goal towards which the action strives.

The great advantage of this particular direction is that it places the moral authority of Jesus in the very centre of consideration. At the same time it avoids demanding that the believer gives a slavishly literal obedience to even the minutest precepts of the Gospel (Lindars, 1973:184-185). An interpretation of the Sermon on the Mount, following this particular direction, views the Sermon as providing a summary of moral principles and not the laying down of rules and regulations for one's conduct. These principles, then, are capable of application to every time and culture. However, it is questionable whether the wealth of the New Testament (and biblical) message can be so neatly summed up in a few ideals. Gustafson (1984:162) has argued that the perspective of eschatology has tended to give support to this direction. The Old Testament looks forward to the fulfillment of an idealized future, while the New Testament proposes the advent of the coming kingdom of God. But, this approach of eschatology as the key to interpreting Biblical ethics for today presents its own difficulties:

One part of the problem is the significance of the eschatological context within the scriptures for understanding properly the biblical visions of future ideals; the other is the authority that the biblical eschatological context has for the use of those visions in constructive theological ethics' (Gustafson 1984:162).

\subsection{Encounter with God}

This direction stresses the free gift of God's Spirit to the individual when reading the Scriptures. Brunner (1937:82-83) epitomizes this perspective when he writes:

The Christian moralist and the extreme individualist are at one in their emphatic rejection of legalistic conduct; they join hands, as it were, in face of the whole host of legalistic moralists; they are convinced that conduct which is regulated by abstract principles can never be good .. There is no Good save obedient behaviour, save the obedient will. But this obedience is rendered not to a law or a principle which can be known beforehand, but only to the free, sovereign will of God. The Good consists in always doing what God wills at any particular moment.

One of the obvious disadvantages of such an approach is that it leads to a too subjective interpretation of the Bible. With the renunciation of laws and principles Christian ethics becomes too individualistic. The Christian religion is above all a communitarian encounter with the saving God and not just an individualistic experience. 


\subsection{An ethics of relations and responses}

The Christian is understood as living in a relationship with the God to whom a response is made in faith and action. The way of life that the Christian embraces is the response that is given to God's activity of salvation which has been demonstrated in the person of Christ.

This approach was opened up by Karl Barth who saw the significance of the Bible as resting not in the revelation of a morality but in the revelation of a living God and his action which called for a response from the believer. Gustafson (1965:309-316) has become the leading proponent of such a relationality-response model for Christian biblical ethics. The human person responds by means of freedom to God's action in the world. Such an approach has also found favourable acceptance among some leading Roman Catholic thinkers as well, such as Curran (1984:182):

I believe that the biblical renewal ... has brought about the same emphasis on the model of relationality and responsibility in Catholic moral theology without necessarily accepting all the presuppositions of a Barthian theology of the Word.

Without doubt this approach gives centrality to the biblical teaching that Christianity is a way of life led in a relation with God. The call issued by Jesus to conversion (metanoia) which initiates this new way of life demands a turning from one mode of existence to another. This new way of life places centrality in following the person of Jesus. Consequently, Christianity is distanced from the perspective of being a religion of norms or goals - instead it is a way of life in which the disciple strives to maintain a relationship to the person of Jesus and to remain faithful to his work.

From my perspective this approach is without doubt the most satisfactory for a number of reasons:

- It respects and comes to terms with the distance between our world and the world of the Bible. The gap is not simply to be bridged in a naive way.

- It sees the purpose of the New Testament as not simply proposing a new morality rather its morality falls within the framework of a revelation of an understanding of God.

- It remains true to the call which the New Testament extends to change one's way of life. The new life to which Christians are called means they must open themselves up to the salvific activity of Jesus Christ and extend this salvation to others. 
Christian biblical ethics: the application of biblical norms to today

* In becoming a Christian the most satisfactory image that captures the new existence is that of a life that is led in a relationship with God and with fellow believers - a life that is a response to what God has done through the saving work of his Son.

\section{LIMITATIONS IN THE USE OF THE SCRIPTURES IN CHRISTIAN ETHICAL DECISIONS}

\subsection{Biblical ethics is not the same as Christian ethics}

It is important to respect the gap between the biblical world and the world of today. Each society takes the information conveyed to it by its senses and organizes it by means of a system of signs which fit together within the total context of that world. One society will look upon its symbolic universe as the real and the factual world, while it will judge another world as strange or archaic (Meeks, 1986:14). This is a point which we in South Africa are only really beginning to appreciate more and more, namely that there are differences inherent in the symbolic universes of our different people. Because the differences are not absolute, communication between the different world views is possible. But, this communication is nevertheless very difficult.

Obviously, the way in which a person acts is influenced by the way in which that person's concept of the world functions. If I believe that devils cause suffering, and that evils in the world are the outcome of my personal sins, my response to the pain I experience when I have a headache, for example, will differ from the response of someone who sees suffering as the outcome of physical causes. The first approach will attempt to overcome the suffering by recourse to someone who can expel devils; the second recourse will be to someone who understands the physical cause and attempts to alleviate it by physical means, by medication, etc.

This demands that one learn to understand the world of the Bible as it is. This is the process that Ricoeur (1981:295) has called distanciation. One attempts to gain an understanding of the world which is alien and foreign to oneself and ultimately to be true to that world by suspending one's own prejudices and ways of viewing the world, in other words by suspending one's own symbolized world.

The methods of biblical exegesis which have been so influential and so successful within this century can contribute towards this process of 'distanciation.' For example, the historical-critical method aimed at trying to recreate and explain the text within the framework of its own world. The socio-historical approach aimed at highlighting more fully the historical, cultural and social world out of which the text emerged and to 
which the text speaks. Within our own country the importance given to the different forms of structural analysis helped to understand the text itself and the relationships within the structure of the text.

Using these various methods or approaches within modern day biblical criticism, one comes to a deeper understanding of the biblical writers within their own symbolized universe. But, the process of interpretation demands more than this. It demands that one move from that world to the world of the interpreter. Ricoeur speaks about this as a dialectic of passing from 'distanciation' to that of 'appropriation.' But, what actually is appropriated? Ricoeur answers this question in the following way. His argument here is most important:

Not the intention of the author, which is supposed to be hidden behind the text; not the historical situation common to the author and his original readers; not the expectations or feelings of these original readers; not even their understanding of themselves as historical and critical phenomena. What has to be appropriated is the meaning of the text itself, conceived in a dynamic way as the direction of thought opened up by the text (Ricoeur, 1976:93).

In line with what has been argued previously, the aim of appropriation is not to take over simply the ideals or norms as specified in the Bible. Instead, one attempts to discover the direction opened up by the Bible, which points towards a relationship that is initiated between God and those whom he has called. This relationship brings with it the call to a response. The Christian believer is called upon to penetrate this meaning more fully in appropriating the biblical message. Reicke's translation of 1 Peter 2:18 is a typical example where the gap between the two worlds is not respected (I am indebted to Curran [1984:188] for this excellent illustration). "You workers, be submissive to your masters with all respect, not only to the good and reasonable ones, but even to the difficult ones" (Reicke, 1964:97). Here Reicke has replaced the original word of slaves, with that of workers and he goes on to say that "Regardless of provocation Christian workers should not rebel or fail in respect towards their employers" (Reicke, 1964:98). That a distinguished biblical scholar should write this is quite astounding. He has willy-nilly replaced one symbol slave by means of another symbol worker and has immediately attempted to import what was said by the one symbolic universe into another totally different symbolical universe. Not only does it fail to respond to the principle of distanciation-appropriation for which we have argued, but it draws conclusions which are totally out of harmony with the meaning opened up by the biblical text. I endorse totally the observation of Curran (1984:188): "I do not think that one can use the Scriptures in this way to argue against the possibility of a legitimate strike by Christian workers." 


\subsection{Against the selective use of Scripture}

This occurs quite frequently in the approach where proof texts are chosen at random because they fit the supporter's presuppositions. The same approach is evident in the choice of certain themes in preference to others. While it is not possible to avoid being selective either in the texts or the themes that are chosen, the real problem arises when these themes are elevated to a central position while all other themes are excluded. This is evident in certain aspects of liberation theology where the theme of liberation acquires central significance, almost to the total exclusion of all other themes, such as themes like order and security which are equally biblical themes (Curran, 1984:194).

\subsection{The relationship between Christian and non-Christian ethics}

In the past the generally accepted position was that the Christian shared an ethical wisdom with all humanity while at the same time possessing a certain revealed wisdom which was contained in the Scriptures. However, today the approach is somewhat different. The question is being posed more and more whether there is really any great difference in content between Christian ethics (revelation and scripture are the reason for its distinctiveness) and any other human ethics.

Obviously, the major difference lies in the very relation of the Christian to God. This relationship must certainly influence the way in which the Christian makes decisions. For the Christian the starting-point for ethical reflections lies in this relationshipresponse. This, however, does not deny the value for the Christian of human ethical reflection on how other people live and give meaning to their existence.

In coming to an ethical decision, it is important to give attention to what the human ethical position has to say in that regard. One can, then, attempt to see whether or in what way this can be harmonized with the direction that has been opened up by the biblical perspective. In this way the biblical and the human work together to give direction to the ethical decision. Christians are not aliens within their own world, but the Christian direction opens up a perspective onto the world. At the same time the world gives direction to the ethical reflection and its perspective within the Christian framework.

\section{ETHICS AS NARRATIVE}

Narratology is a more recent approach towards interpreting the Bible, and Hauerwas has been largely successful in using the concept of narrative as a hermeneutical key to 
understand the moral direction of the New Testament. The narrative of the Scriptures concerns above all the existence of a community, firstly the community of Israel and then later the community of the early church. These communities bear witness to their encounter with God and how they and God responded to each other. At the same time the very existence of Scripture presupposes a community which has preserved these writings as authoritative. The writings continue to act as a challenge to each new situation and new community "to be the kind of people capable of recalling the stories of our fathers and mothers, on which our existence continues to depend" (Hauerwas, 1984:261).

When examining the ethical significance of the Scriptures, the most important consideration that emerges is the question as to what type of community the Christian community must become so that the narratives of Scripture can have central meaning for the lives of the Christian (Hauerwas, 1984:261). First of all, it must become a community that is able to remember the stories of Israel and of the early church and for whom these stories become authoritative. The biblical narrative of Israel and the early church portrays a picture of a community that is in a relationship with the God who has communicated his forgiveness. The memory that the present community of Christians carries with them is that "we learn how to be a people morally capable of forgiveness and thus worthy of continuing to carry the story of God we find authorized by Scripture" (Hauerwas, 1984:262).

In remembering the narratives of Scripture the Christian community sees reflected above all the direction of response-relationality. God acts in Israel and his Son Jesus in order to bring salvation and forgiveness to his world. Israel and Jesus respond to this activity of God and in this way their relational-response becomes a paradigm for the way in which the Christian today is to act. The meaning opened up (as Ricoeur would express it) by the narrative becomes normative for the response called forth by the Christian.

\subsection{The call to respond in faith to the way of life of Jesus of Nazareth}

Ultimately the responsibility to which individuals are called is a responsibility for what they alone are accountable. The only specific test of the correctness or rightness is how honest the individuals are in response to the demands made by faith (Fisher, 1984:168). They see their faith reflected in the Scriptures in the stories of Israel and of Jesus. "By learning to imitate Jesus, to follow in his way, the early Christians believed they were learning to imitate God, who would have them be heirs of the kingdom" (Hauerwas, 1983:178). 
God's way with Israel was in turn his way with Jesus, and ultimately his way with Christians of all times. Consequently, by imitating the way of Jesus the early Christians believed they were responding in the way in which a disciple should. Above all the life of Jesus was a life of service, trust and love and this in turn becomes the life that the Christian must lead.

Our use of the Scriptures then is not to see them as moral law books containing lists of ethical norms to be implemented, nor as ideals for which we strive. Instead, we use the Scriptures as a narrative of God's dealing with the world, firstly as exemplified in the nation of Israel and secondly as exemplified in the person of Jesus. Christians are called forth to respond in a similar vein to God's forgiving love within their lives by bringing this forgiving love to others. It shows as well that the Christian is not called to a response in isolation or as an isolated individual. God is calling the individual to a response as part of a community, the church. "The question of the moral significance of scripture, therefore, turns out to be a question about what kind of community the church must be to be able to make the narratives of scripture central for its life" (Hauerwas, 1984:261).

\subsection{A life of vision}

The above consideration shows that the Christian life in its essence is a life which learns to view the world in a specific way informed by the narratives of the Scripture. This means, as has been consistently argued, that the narratives of Scriptures are not presenting norms or ideals but rather a vision that calls forth a response of relationality. Christians have a common view on the world and see things in a way that is determined by the narrative of the Scriptures.

What is this vision that informs the Christian view of the world? This vision must take account of five perspectives fundamental to the Christian stance:

- Creation - God's way of life with the world.

- Sin - God's response of forgiveness to humanity who has rejected him.

- Incarnation - God's sending his son to show the way to reconciliation.

* Redemption - the communication of God's forgiveness to humanity through the death of his son.

* Resurrection destiny - the hope for which the believer strives: the ultimate destiny of union with God (Curran, 1986:84).

Such an approach makes it possible for a Christian to take a view of the modern world and attempt to come to terms with ethical issues within this framework. This vision of 
the world clarifies more fully what was said in the previous section of responding to the way of life of Jesus of Nazareth which recapitulates God's way with the world and Israel. The purpose of such a vision or stance helps the Christian to understand the world and to see actions within this perspective. Decisions stem from one's stance on the world. The Christian's stance, as has been indicated, is informed by the fivefold perspective of creation - sin - incarnation - redemption - resurrection destiny. When acting, it will be this stance which influences what the individual does. Before taking this up more practically by referring it to the issue of homosexuality, I would like to draw together the major thrust of my argument.

\section{METHODOLOGICAL APPROACH IN MAKING AN ETHICAL DECISION}

\subsection{The starting-point}

The starting point for all ethical reflection or decisions are the problems that arise from the present which require some explanation or resolution. This means that one selects those biblical passages which most closely approximate the problems which call for a decision.

5.2 In examining those biblical images respect must be had for the following points that have been argued:

* The gap between the present and the past must be respected. The process of 'distanciation' must be first of all respected.

* The biblical images or passages must be explained according to all the hermeneutical principles that are presently available. The meaning opened up by the text must be discovered before one can make an appropriation to today.

\subsection{Respect for biblical images}

Respect must also be had for the way in which these biblical images fit within the vision or stance on the world which the biblical revelation promotes. Very often a decision is not based on a rational argument, but is the simple outcome of the vision that one has of the world. The Scriptures open up a vision which presents a narrative of God's dealings with the world and how he calls forth a response from those who are in a relationship with him. The search is not so much for ethical norms, decisions, or goals, as for an attempt to discover how the problem fits within the Christian stance or 
vision called forth by the biblical narrative. Christianity is distanced from the perspective of a religion of norms or goals. Instead, it is a way of life in which the disciple strives to maintain a relationship to the person of Jesus and to remain faithful to his work.

\subsection{Scientific ethical reflection}

Attention must also be given to scientific ethical reflection to see how the ethical community views the problem and the images inherent in the problem. This crossreference is a corrective in order to examine the problem from another angle. This does not mean that one simply embraces this viewpoint, but one uses it as a challenge to see what the ethical scientific viewpoint can contribute to the biblical vision that has been so far discovered. This has particular significance especially in those areas where the Bible says little or nothing about the problem at hand. As argued above, biblical ethics and scientific ethics should not be seen to be in opposition, but rather together they can lead to a deeper appreciation of the problem and its resolution.

5.5 The decision must ultimately be judged in the context of the faith of the learning Christian

The Christian does not act alone, but the decision is supported and guided by the Christian community. "What the biblical author wrote arose from the community. So also the reader must be aware of the community as a source of interpretation and as recipient of communication from the reader" (Daly, 1984:294).

Be that as it may, the community does not give some infallible certainty that the action is correct. One cannot simply measure the rightness or wrongness of an action by means of an opinion poll. In the ultimate analysis the only criterion for sincere Christians is honesty with themselves and with the way in which they have endeavoured to come to a solution to their problems.

\section{APPLICATION TO THE TEST CASE OF HOMOSEXUALTYY}

\subsection{The starting-point}

In the world of today the issue of homosexuality is receiving more and more attention. More and more pain is being experienced by Christians who on the one hand discover 
their sexuality as having a same-sex orientation, yet at the some time this appears to be in contradiction to what their Christian faith expresses from its biblical foundations. A very good example of this was seen here in South Africa very recently in the reaction evoked by the book Om gay te wees: straf of seën? (Pretorius, 1990). Here an honest attempt was made to give expression to the author's understanding of his own sexuality against the background of his understanding of the Bible and his Christian faith. The amount of controversy provoked by this in the national newspapers and television was quite phenomenal. Consequently, this issue provides an excellent test-case for examining the application of the methodology outlined above. While homosexuality is not strictly speaking a medical issue, it is an issue within the related disciplines of psychology, psychiatry and psycho-analysis. The intention here is not so much to make a study of homosexuality as such, as to illustrate one example of how to proceed in solving an ethical problem within the context of the biblical perspective. The startingpoint, as has been indicated previously, means selecting those biblical passages which most closely approximate or deal with the issue of homosexuality.

\subsection{Examination of those biblical passages that speak of homosexuality}

There are seven passages in the Bible which speak of homosexuality and appear to condemn it in forceful terms. This is the way these passages have been traditionally interpreted. However, the major fallacy in such interpretations is the failure to pay attention to the principle of 'distanciation' or to see the gap between the symbolic universe of the Old and the New Testament and our own symbolic universe.

\subsubsection{The Old Testament testimony}

\subsubsection{The story of Sodom and Gomorrah (Gen. 19:4-11)}

Here we are aware that this passage falls into a narrative which forms part of the early story of the forefathers of the Israelite nation. It must be understood and interpreted against the background of a narrative or a story that is unfolding. The narrative does not condemn homosexuality as such, nor even homosexual acts. What is condemned is the intention to commit homosexual gang rape in the context of a disregard for the law of hospitality (Vawter, 1977:233-234; Sarna, 1966:144-145). In reading this narrative today one must respect the 'gap' that exists between the world of the Bible and the world of today. One tends to overlook the sacred nature of the call to hospitality. In the Ancient Near East, as the Bible frequently testifies, hospitality to those who are travelling is not simply a voluntary option - it is a duty. 
When an alien resides with you in your land, do not molest him. You shall treat the alien who resides with you no differently than the natives born among you: have the same love for him as for yourself; for you too were once aliens in the land of Egypt. I, the Lord, am your God (Lev. 19:33-34).

The emphasis of the passage, no matter what the intentions of the men of Sodom, is to stress the obligation of hospitality. This emerges clearly from verse 8: "But don't do anything to these men, for you know they have come under the shelter of my roof."

A further insight with regard to this verse again stems from the symbolic universe of its world. Sexual relations between humans and angels was considered totally evil in Jewish eyes because it was between two different orders of creation: humanity and the angels. The disaster of the flood in Genesis 6:1-8 was judged to be an outcome of this relationship between angels and humanity. The fact that the men in this narrative were angels is a fact that was known only to God and the author of this story - not to the townspeople. Consequently, the author stresses the goodness of Lot in upholding the order of creation.

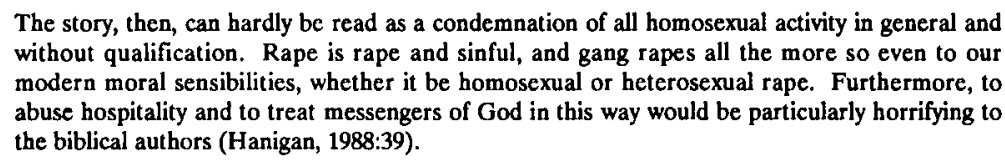

The story, then, can hardly be read as a condemnation of all homosexual activity in general and without qualification. Rape is rape and sinful, and gang rapes all the more so even to our modern moral sensibilities, whether it be homosexual or heterosexual rape. Furthermore, to abuse hospitality and to treat messengers of God in this way would be particularly horrifying to the biblical authors (Hanigan, 1988:39).

Jewish commentary on this Sodom story does not specifically view the sin referred to as homosexuality. For example, Isaiah 1:9ff and 3:9 see it as a lack of social justice. Ezekiel 16:46-53 refers to it as disregard for the poor. Even the Talmud and the Misnah prefer to see the sin of Sodom in connection with sins of pride, arrogance and inhospitality and only once do they give it a meaning of homosexuality (Barnett, 1979:10).

Judges 19:22-30 contains a similar account to that of Genesis 19. Again the host is asked to betray his duty of hospitality by handing over his guest so that the men of Gibeah can sodomize him. The thrust of the narrative is once again on the aspect of betrayal of hospitality.

Even though the secondary aspect of the narrative concerns intended homosexual rape by the citizens of Sodom and Gomorrah, it is to be noted that the narratives actually concern heterosexual males who wish to perform homosexual acts as a sport. This interpretation is supported by the fact that the offer in both stories of giving them women instead would have no sense. This insight is important in its context. 


\subsubsection{The laws in Leviticus 18:22 and 20:13}

Both laws are part of the Holiness Code in the Book of Leviticus. What these texts expressly forbid is that a man should lie with another man as with a woman. No reason is given as to why it is viewed as such an abomination before God that it deserves the death penalty. Within the symbolic universe of early Israel this type of action was consequently deemed abhorrent. One can only but guess at the reasons for this.

First of all, one notes that this occurs in both contexts in relation to other sexual sins. Taken in connection with the other sins that are listed whereby they are forbidden to have carnal relations with an animal, one can see behind it the typical outlook on the world common to other people. Like them the Israelites did not have our understanding of how conception takes place. It was the male seed alone which was judged responsible for generating the new living person. The woman was merely the receptacle for that seed. Consequently, the prohibition concerns the concept that man is not to sow his seed in another man where it would be unproductive. Likewise with regard to an animal where it would lead to a confusion in the order of the world and some monster might be born.

A further point worth noting in this context of the examination of the image of homosexuality is that even if these texts do explicitly forbid homosexuality as such, why should they be taken as binding on the Christian while other texts are not? The question of 'distanciation' or respecting the 'gap' between the two worlds again arises. For example, in exactly the same chapters if a man has intercourse with his wife during her menstrual period (Lev. 18:19 and 20:18) he is to be banished from the community. On what grounds is one law seen as applicable to the Christian, while other laws are not?

Although the Old Testament texts do pass a judgment on homosexual acts, a number of questions still remain open. Their condemnation seems related to the symbolic world which they have constructed and in which these images function. As has been shown methodologically, one cannot simply take these laws and images and immediately insert them into our own symbolic world, which is vastly different. The distinction must clearly be kept in mind that while the biblical author may intend to forbid all homosexual actions, he is speaking from out of the perspective and understanding of his own world. This means that an immediate one to one identification with our world is not possible, because it has not given sufficient attention to the principle of distanciation as was outlined previously. 


\subsubsection{The New Testament tradition}

\subsubsection{Romans 1:26-27}

This appears to contain a direct condemnation of sexual relations between men. However, this condemnation must be seen within the context of the letter to the Romans itself. In fact the context shows that Paul is not speaking directly to the ethical issue of homosexuality, but is rather concerned with the theological issue of idolatry. Because humanity has turned away from God to the worship of idols, God then gave them over to their 'degrading passions.' Paul explicitly states that men gave up intercourse with the opposite sex for intercourse with one another. He has in mind heterosexual males who gave up their natural orientation to embrace a homosexual orientation which was contrary to their nature. In a detailed study of this passage Scroggs (1983:109-118) has argued that the passage must also be understood against the cultural world of that time. In reference to homosexuality the aspect that Paul would have had in mind would be that of pederasty. For Paul the basic sin that he is concerned with is the refusal to acknowledge God as God. This idolatry would be demonstrated in a life in which the practice of pederasty (which was widespread in the Greco-Roman pagan world) was one of the evident examples of alienation.

The conclusion to be drawn from this is that the intention of Paul in this passage is theological not ethical. Idolatry is the main thing that he is incensed about. While the example of homosexuality is exactly that - an example, the cultural world of the time must be used to explain what is referred to and why it is condemned. Again the principle of distanciation must be respected before one immediately latches on to two verses and uses them as authoritative for the present.

\subsubsection{Corinthians 6:9 and 1 Timothy $1: 10$}

These are the final passages that conceivably touch on homosexual behaviour.

In 1 Corinthians 6:9 Paul asks: "Do you not know that the unjust will not inherit the kingdom of God." He then proceeds to list those categories of people who will be excluded from God's kingdom: "... neither fornicators, nor idolaters, nor adulterers,

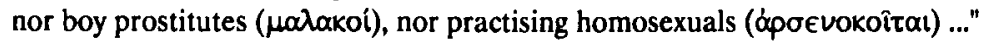

In 1 Timothy 1:10 Paul is speaking in the context where he indicates that the law is "meant not for a righteous person, but for the lawless and unruly ..." and then he goes on to indicate specific examples amongst whom appear once again "practising homosexuals (apoevokoitals). 


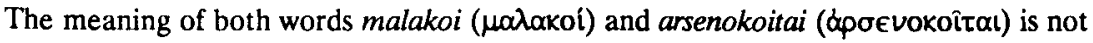
easy to determine. Consequently, it is not clear just exactly what sexual practices they have in mind. Louw and Nida (1988:772, paragraph 88.280) define it as: "It is possible that ópo€vokoitns) in certain contexts refers to the active male partner in homosexual intercourse in contrast with $\mu a \lambda a k o ́ s$, the passive male partner."

Given the studies made by Scroggs of homosexuality in the ancient world and particularly with reference to the New Testament, his conclusion in reference to these texts is important:

\footnotetext{
I thus draw the conclusion that the vice list in 1 Timothy is not condemnatory of homosexuality in general, not even pederasty in general, but that specific form of pederasty which consisted of the enslaving of boys or youths for sexual purposes, and the use of these boys by adult males (Scroggs, 1983:120-121.).
}

\subsubsection{Summary}

The biblical texts examined show firstly a certain vagueness concerning the reasons for the condemnation of homosexuality. These reasons are ultimately to be sought within the framework of their symbolic as well as cultural world which is not always readily accessible to us. One certainly cannot say that the meaning that is opened by the examination of this alien world is that all homosexual acts are to be condemned as evil. This would certainly be an illegitimate appropriation to make of the distanced text. The conclusion arrived at by Scroggs is to be supported, namely that "biblical judgments against homosexuality are not relevant to today's debate. They should no longer be used in ... discussions ... not because the Bible is not authoritative, but simply because it does not address the issues involved" (Scroggs, 1983:127).

A consideration of those passages dealing with homosexuality is not sufficient to answer the problem. One needs to see it against the background of human sexuality, its nature and purpose. However, before doing this it is necessary to pay attention to what scientific ethical reflection today has to say with regard to homosexuality.

\subsection{Scientific ethical reflection on homosexuality}

In returning to the methodological approach outlined it was argued that attention must also be given to scientific ethical reflection to see how the ethical community views the problem. Today the American psychological community has rejected the classification of homosexuality as an abnormality, or a neurotic or personality disorder. Instead it is referred to as an alternate sexual preference (Batchelor, 1980:2-3). While there are no 
agreements on the causes of homosexuality, a certain number of things have emerged which are universally accepted as clear.

There is a distinction between the irreversible homosexual orientation and the occasional feelings of homosexual attraction. A homosexual orientation, just as a heterosexual orientation, involves the whole being and gives the person sexual direction. The sexual orientation is not a matter of deliberate choice, but is a 'given' of one's nature.

At the same time there is a distinction to be made between orientation and behaviour. This means a distinction between what one is and what one does. From an ethical perspective one can say that "to be a person whose sexual orientation is predominantly homosexual or heterosexual is neither praiseworthy or blameworthy " (Hanigan, 1988:36). Ethical judgment and discussion enter in only when one considers the behaviour and the action, that is ethical judgment concerns what one does with one's sexual orientation. Looking back at the biblical perspective one sees that the biblical world had no concept whatever of such a perception as a homosexual orientation. The perspective of their symbolic world could only conceive of someone with a heterosexual orientation acting contrary to this by performing homosexual actions. The distinction between the different world views emerges more clearly; one cannot simply import the one into the other and make it normative.

\subsection{The context of the faith of the learning Christian}

How does what has been said fit within the wider vision of the biblical revelation and the faith of the community?

The Christian world appropriated the biblical vision that the God of creation intended monogamous marriage between male and female as that towards which human sexuality was directed. "This is why a man leaves his father and mother and clings to his wife, and the two of them become one body" (Gen. 2:24). Further to this, the purpose of this sexual union was understood to be for the procreation of children: "Be fertile and multiply; fill the earth and subdue it" (Gen. 1:28).

The Christian vision has come to see human sexuality not simply as directed towards the procreation of the human race, but also as the means for expressing a loving relationship between a couple which aims at permanency. In fact, given the situation that not every sexual act in marriage is open to the procreation of children, the primary end of marriage must be the uniting of husband and wife in a bond of mutual love. 
While the ideal of human relations exists in the male-female relationship of a couple expressing their love for each other in a relationship that strives for permanency, I think it is possible to make an argument as some scholars do (such as Curran, 1979:71 ff) in support of a couple with irreversible homosexual orientations entering into a loving relationship that is striving for permanency. This would be seen to be morally good.

In saying this, a number of factors need to be stressed. The irreversible homosexual orientation is not the specific choice of the individual. His nature is what it is and every being is called upon to act according to its nature: agere sequere esse (morality follows from our being). This is not to say that every homosexual action is good: not at all. One is simply referring to those individuals whose orientation is of such an irreversible nature. It also means that the action must take place, as with a heterosexual couple, within the context of a loving relationship which strives for a permanent bond.

The ethical model that I have painted before as the way to ethical action is that of response-relationality. In this sense one can see the irreversible homosexual responding in a loving relationship which conforms to his nature. The individual is not free to choose either a heterosexual or homosexual direction. Sexuality is not neutral in this sense. One discovers one's sexuality and its orientation and must act accordingly.

Within the vision or stance of biblical revelation one can see this perspective fitting in the following way. It was previously pointed out that the Christian stance or vision incorporates five basic mysteries: creation - sin - incarnation - redemption resurrection hope. The notion of sexuality must be seen against this background. From the perspective of creation the ideal meaning of sexual relationships is undoubtedly in terms of male and female. However, the world is not as it was originally created. Sin has entered the world and with it creation has undergone a change. The 'sin of the world' affects some individuals without affecting others.

Seen in this light the irreversible homosexual orientation is judged to be a consequence of the entry of sin into the world and a distortion of the ideal world. This in no way means that the individual homosexual is morally evil or bears personal moral guilt (Curran, 1979:76-77). Just as a person who is born a cripple can see his position as a consequence of the limitations of our world and how the world does not always attain its perfection or ideal, so with the homosexual. 


\section{CONCLUSION}

I believe that the approach outlined above does justice to the various sources essential for the ethical decision of the Christian believer. It has endeavoured to be true to the Scriptural evidence and the way it has been accepted within the Christian community.

The examination of the use of the Bible today argued for a fivefold development. The example given has endeavoured to remain faithful to this methodological process by looking at biblical passages which were appropriate to the problem. However, these passages were examined against the perspective of their world view and the symbols that construct that view. This approach has distanced itself from the naive application of biblical norms from one symbolic world to another different symbolic world on an immediate one to one basis. The attempt was also made to show how the biblical images fit within the wider vision or stance of biblical revelation.

Attention was given to the modern scientific ethical reflection on this topic. Consequently, one notices how the direction or vision that was opened up by the biblical revelation is now able to be appropriated within the present world view. This demanded as well that this appropriation continues to remain true to the faith of the believing community in which the ethical reflection has taken place.

The ethical issue of homosexuality has illustrated this methodology very clearly. While this solution distanced itself from a naive biblicist interpretation, at the same time it has not accepted a naive endorsement of every form of homosexuality. Instead, it has attempted to take seriously the discoveries and findings of modern psychology and psychiatry, while incorporating and correcting them within the context of the Christian vision and stance of the world.

\section{BIBLIOGRAPHY}

BARNETT, W. 1979. Homosexuality and the Bible: an interpretation. Lebanon : Pendle Hill Publications.

BATCHELOR, E. 1980. Homosexuality and ethics. New York : Pilgrim.

BRUNNER, E. 1937. The Divine Imperative. (Tr. by O Wyon). London : Lutterworth.

CURRAN, C.E. 1979. Moral theology, psychiatry and homosexuality. (In Transition and tradition in moral theology. Notre Dame : University of Notre Dame Press. p.59-80.)

CURRAN, C.E. 1984. The role and function of the Scriptures in moral theology. (In Curran \& McCormick 1984. p. 178-212.)

CURRAN, C.E. 1986. Faithful dissent. London : Sheed \& Ward.

CURRAN, C.E. \& McCORMICK, R.A. 1984. Readings in moral theology. No 4: The use of Scripture in moral theology. Paulist : New York.

DALY, RJ. 1984. Christian biblical ethics. From biblical revelation to contemporary christian praxis: method and content. New York : Paulist. 
FISHER, J. 1984. Story and image. (In Daly 1984:156-169.)

GUSTAFSON, J.M. 1965. Christian ethics. (In Ramsey, P. ed., Religion. Englewood Cliffs : PrenticeHall. p. 309-316.)

GUSTAFSON, J.M. 1984. The place of Scripture in Christian ethics: a methodological study. (In Curran \& McCormick. p. 151-177.)

HANIGAN, J.P. 1988. Homosexuality: the test case for Christian sexual ethics. New York : Paulist.

HARTIN, P.J. 1987. New Testament ethics: Some trends in more recent research. Joumal of Theology for Southem Africa, 59:35-42.

HARTIN, P.J. 1990. Methodological principles in interpreting the relevance of the New Testament for a new South Africa.

HAUERWAS, S. 1983. The peaceable kingdom: a primer in Christian ethics. Notre Dame : University of Notre Dame Press.

HAUERWAS, S. 1984. The moral authority of Scripture: The politics of remembering (In Curran \& McCormick. p. 242-275.

LINDARS, B. 1973. The Bible and Christian ethics: Duty and discernment 3. Theology, 76:182.

LONGENECKER, R.N. 1984. New Testament social ethics for today. Grand Rapids: Eerdmans.

LOUW, J.P. \& NIDA, E.A. ed. 1988. Greek-English Lexicon of the New Testament based on semantic domains. Vol 1 \& 2 . New York: United Bible Societies.

MEEKS, W.A. 1986. The moral world of the first Christians. Philadelphia : Westminster.

PRETORIUS, H. 1990. Om gay te wees: straf of seën? Pretoria: Homofilos

REICKE, B. 1964. The Epistles of James, Peter and Jude. The Anchor Bible. Garden City : Doubleday.

RICOEUR, P. 1976. Interpretation theory: discourse and the surplus of meaning. Fort Worth : Texas Christian University Press.

RICOEUR, P. 1981. Hermeneutics and the Human Sciences (ed. by J B Thompson.) Cambridge : University Press.

SARNA, N.M. 1966. Understanding Genesis: the heritage of Biblical Israel. New York : McGraw-Hill Book Company.

SCROGGS, R. 1983. The New Testament and homosexuality. Philadelphia : Fortress.

SCROGGS, R. 1985. The New Testament and ethics: How do we get from there to here? (In Talbert, C.H. ed. 1985. Perspectives on the New Testament: Essays in honor of Frank Stagg. Macon : Mercer University Press. p. 77-94.)

VAWTER, B. 1977. On Genesis: A new reading. Garden City : Doubleday. 
